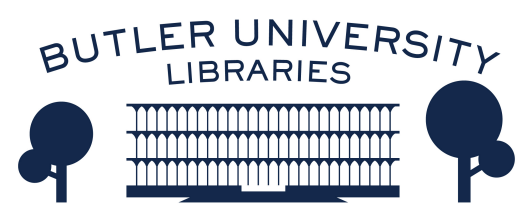

Journal of Hindu-Christian Studies

Volume 1

Article 8

January 1988

\title{
Viewpoints: Dialogue in the Modern West
}

Klaus Klostermaier

Follow this and additional works at: https://digitalcommons.butler.edu/jhcs

Part of the Religion Commons

\section{Recommended Citation}

Klostermaier, Klaus (1988) "Viewpoints: Dialogue in the Modern West," Journal of Hindu-Christian Studies: Vol. 1, Article 8.

Available at: https://doi.org/10.7825/2164-6279.1008

The Journal of Hindu-Christian Studies is a publication of the Society for Hindu-Christian Studies. The digital version is made available by Digital Commons @ Butler University. For questions about the Journal or the Society, please contact cbauman@butler.edu. For more information about Digital Commons @ Butler University, please contact digitalscholarship@butler.edu. 
discussions and seminars brings about a better result, creating fellowship among participants of different religions. This mode of dialogue is gaining ground among many dialogue groups that have been meeting for a number of years.

On the part of the Christians in India, dialogue with Hindus has had a different phase of growth. Dialogue began as a process of inculturation and Ashram movements where an openness towards and appreciation for Hindu religious texts and symbols created an enthusiastic climate among many. In 1970s, this process was at its height and adapting names and symbols of Hindu tradition had its own impact, though there was also opposition from some sections of the Christian cornmunity in India. Today a discerning person would evaluate such a phase of inter-religious 'dialogue' as no dialogue at all. Though one perceives an apparent openness to another religion in this venture, on further consideration one discovers that a superficial incorporation of elements of another religion into one's own is a lack of dialogue. An exposure to the supermarket of religious beliefs and practices does not necessarily broaden one's religious perspective but through confusion narrows down the scope of dialogue.

However this particular phase of dialogue has enabled some in 1980 s to focus their attention into their own theological framework. The motives of dialogue are not always clear. One can pick up a wide range of motives among different dialogue partners depending upon their theological vision to engage in dialogue.

Attempts have been made already to articulate the pre-requisites of dialogue. For instance Paulose Mar Gregorios lists ten principles to be kept in mind while engaged in dialogue with other religions. ("Dialogue with world Religions. Basic Approaches and Practical Experiences". Indian Journal of Theology 1980, vol. 29, pp. 1-11). Leonard Swidler gives ten commandments concerning attitudes necessary for partners in dialogue ("The Dialogue Decalogue: Ground Rules for Inter-religious Dialogue" Journal of Dharma vol. 8. (1983) pp. 311-315). Such formulations envisage a phase of growth in which the dialogue partners are brought face-to-face with the as-yet-unknowndimension of reality and the possibility of change has been introduced. This change is the result of dialogue, for in a genuine dialogue one cannot remain unaffected if there is any involvement at all in this process. Secondly, by one's readiness to participate in a dialogue situation a certain acceptance of another's position and also certain validity is granted. Otherwise, there will be no dialogue or discussion taking place.

Given these presuppositions some of the writings on dialogue by Christian theologians do not clarify their stand with regard to certain issues like Evangelisation versus dialogue. Some hold that Proclamation of the Kingdom and dialogue are complementary. Others assert that dialogue does not mean the abandonment of Evangelism. It still appears that dialogue is a preparation for proselytisation. When a commission on dialogue and a commission on direct evangelisation are set up by the same organisation side by side and sometimes the same participants move in and out of these commissions one begins to wonder about the consistency of their theological vision and raise doubts about the motives of such a dialogue initiative.

In India, dialogue takes place also in another form with different headings such as national integration, secularism and so on because of the Indian situation. The secular state, understood as favouring no one particular religion but treating all religions equally, presupposes that its citizens respect the others' convictions and freedom to practise their religions. When India needs collaboration from all to build up a national community, one has to uphold common values that can sustain pluralism. One cannot talk in terms of coexistence, but needs a philosophy of preexistence, living for the other. That is why inter-religious forums take up issues of communal harmony, human solidarity, national integration, and so on. The newsbulletin of such centres and associations do highlight values such as justice, harmony, equality, personal dignity and so on as common to all. Their praxis-oriented programmes of action and study play a vital role in promoting genuine dialogue among đifferent religious groups.

Given the composition of the Indian
Society with differences in religion, Inaguage and community affiliation, dialogue becomes a necessity and by and large the well-meaning people do perceive it especially in the context of communal riots, minority-majority equations, demand for recognition as different ethnic groups and so on. Dialogue is usually associated with religions or at least with a religious attitude. Even when dialogue takes place at the socio-cultural forums, the theological perspective of this concept cannot be undermined, for dialogue should after all stem from a faith-horizon and a theological vision. That is why a survey of Hindu-Christian dialogue places the emphasis on what is going on between major religious communities.

Anand Amaladass

Institute of Philosophy and Culture

Madras, India

\section{Dialogue in the Modern West}

"Mankind's religious future may be obscure; yet one thing is certain: The living higher religions are going to influence each other more than ever before."

Arnold Toynbe

The Calgary Conference on HinduChristian Dialogue in September 1987, at which the idea of this bulletin was conceived, brought people together who came from places as distant as Hong Kong and Madras, Hamilton and Winnipeg, Kansas City and New York, Tokyo and Santiniketan, Waterioo and Geneva, Edmonton and Regina. Most of the participants had met before somewhere else-very often in places very far from Calgary. All the Easterners present had lived for extended periods in the west, all the Westerners had been to the East-some for many years. While the participants of this meeting may not have been typical for just any group of people meeting in conference at Calgary, they did typically represent the kind of cosmopolitanism connected with gatherings on interreligious dialogue. The conference topic "Hindu-Christian Dialogue" assigned roles to some as "Christians" and to others as "Hindus". But all those present were aware that these were fairly artificial boundaries. "HinduChristian Dialogue" is part of a wider interreligious dialogue which again is 
symptomatic for an era of increasing physical and mental mobility of intellectuals. If, for instance, I were asked to describe my cultural or religious identity to an outsider I would be hard pressed to come up with an answer that would make sense to a person who has never left his or her hometown and never been to a church but the one s/he was baptized in.

For many of us there are no longer any clear boundaries between East and West, between this tradition and that, between-in our case-Christianity and Hinduism. We recognize, of course, the existence of legal and physical bodies that carry certain labels, the attempts in either camp make humans conform to these labels, the efforts to give socio-political meaning to Christianity and Hinduism so as to polarize and set off people against each other. The Calgary Conference on Hindu-Christian Dialogue may have been the first such major meeting in Western Canada-it certainly is no longer an unheard-of or wildly daring thing to do. Many such dialogue meetings have taken place in India, in Europe, in NorthAmerica and many more will take place in the years to come.

Hindu-Christian dialogue-or for that purpose, interreligious dialogue as such, may not be as much in the news today as it was twenty years ago, when it was a fairly risky and controversial matter. But it continues, on a broader basis perhaps, than ever before. One of the reasons for this state of affairs is the existence of programmes for the study of religions in many countries, especially in North America.

Whether they explicitly advocate dialogue or not, the teachers of History and Religions prepare for it in numerous ways by informing their students about different religious traditions, inviting them to reflect and compare. Courses like "Introduction to World Religions" have become quite popular over the past twenty years and by now there must be hundreds of thousands of men and women who possess some understanding of, and some sympathy for, religions other than their own. In contrast to the generation of their parents, today's American or European visitors to India are no longer horrified by images of Hindu gods and goddesses and they feel no longer that they are compromising their Christian faith by visiting a temple, by participating in a Hindu ceremony or by listening to the exposition of a Hindu scripture by a Hindu guru. Certain cultural barriers remain, of course, and probably will never be totally overcome. But on a basic human and religious level many barriers between Hindus and Christians have disappeared.

By now many millions of Hindus live in the West. Some have become totally absorbed by their surrounding culture, others have maintained large parts of their traditions. Hindus have built temples in Europe and North-America, they maintain religious associations, they are represented through a variety of Hindu missions and organizations. Departments of Religious Studies have quite frequently teachers with Hindu-background on their staff who would, often without calling it that way, engage in a Hindu-Christian dialogue with students coming from a Christian background.

Ours is not a particularly virtuous age and by comparison with former ages we may appear as not only less religious but also less moral and less disciplined. But we may take some pride in one thing which sets us off from previous ages in a more positive way: there is greater openness and honesty today in matters where formerly dissimulation and hypocrisy were the rule. We dare to admit that we disagree with authorities-secular as well as religious-and we dare to express our disagreement. We have the courage to use our own eyes to see for ourselves and our own minds to think for ourselves also in matters of religion and morals. We need this independence of mind and heart if we want to meet in dialogue with people from other traditions, who may have had to fight equally hard against prejudice and pretense, against petrified tradition and vested religious interest.

In spite of the all too evident decline of the influence of the Churches in the West and the disaffection of the younger generation with traditional religion in the East, it may not be too bold an assertion to say that at no time has religion been taken so seriously by so many students at universities. The theological faculties of the past (and many of the present as well) were closed institutions which appealed to, and catered for, only a very small number of people who wanted to enter into a ministerial career. Quite often it was not the large human concerns and the great religious issues which were at the center of attention in these institutions but the specifics of a particular tradition, the rules and regulations which held the profession together. Both by inclination and by training most of the products of these institutions would be ill equipped for and ill disposed towards interreligious dialogue.

Things are different with students in programmes of religious studies. Not all are deep thinkers, but all are interested in a variety of religions. Not all share the same concerns, but many are open for dialogue and for a kind of religious universalism. While I am fully aware that the real world is larger than the university, I would maintain that it would be a grave mistake to consider the university today as an ivory tower and to believe that the things that go on within its classrooms would not be relevant for the population at large. What is done in departments of religious studies today will, sooner or later, have its repercussions also on the way religion is seen and practiced in society at large. I tend to think that this is a good thing. It will not only facilitate HinduChristian dialogue by making it appear natural that Hindus and Christians meet and talk to each other but it will likely also change the direction of the HinduChristian dialogue in ways we can only speculate about.

Klaus Klostermaier, Chair

Department of Religion

University of Manitoba

Winnipeg, Manitoba, Canada

\section{NEWS:}

\section{Three Dialogue Centres In India}

\section{Maitri Bhavan (Varanasi)}

Maitri Bhavan is a small "Dialogue Centre" or "Interreligious Meeting House" in Varanasi, the holy pilgrimage and cultural centre of the Hindus. It was started in 1980. In the beginning the centre was housed in a small apartment in the city. Since January 1988, it has its own house close to the Benares Hindu University and the holy river Ganges.

Varanasi or Benares is a city sacred to the Hindus, Buddhists and Jains. About $12 \%$ of the city's population are Muslims, 